\title{
System Dynamics Modelling of Deforestation Rate and Forest Rehabilitation in the Upstream of Ciliwung Watershed, Bogor Regency
}

Andi Setyo Pambudi ${ }^{1}$

Ministry of National Development Planning (Bappenas)

Corresponding author. Email: andi.pambudi@bappenas.go.id

Submitted: June $14^{\text {th }} 2020$ | Accepted: September $21^{\text {st }} 2020$ | Published: September $28^{\text {th }} 2020$

\begin{abstract}
One of the strategic watersheds in Indonesia is the Ciliwung watershed. The rapid growth of development in this watershed has resulted in reduced forested lands and water catchment areas. The critical point is when the upstream area as a buffer zone also experiences uncontrolled land conversion for various purposes. Indonesia Law Number 41 of 1999 concerning Forestry, Article 18 contains a mandate for the Government to determine and to maintain the adequacy of forest cover in each watershed. This research seeks to understand the condition of rehabilitation and deforestation of forested land in Bogor Regency as the upstream of the Ciliwung watershed which affects its downstream water system in DKI Jakarta Province. By applying system dynamics modelling, it is expected that an ideal scenario of rehabilitation which the government must undertake will be identified to cope with deforestation rates in forested upstream watersheds. The methodological approach applied in this paper is a mixed method with system dynamics-based analysis methods. The results of model simulations carried out in Business as Usual conditions and Simulation of Scenarios Model going forward to 2060. From the alternative scenarios available, it reveals that the rehabilitation capability scenario of $3.6 \%$ / year is the most optimal to overtake deforestation rates in the upstream Ciliwung watershed. If the simulation setting is extended to 2100 , the maximum area of forested land in 2090 will be $8,134.05$ ha (still below the carrying capacity of the available forest area).
\end{abstract}

Keywords: Watershed, Deforestation, Rehabilitation, System Dynamics 
Andi Setyo Pambudi

\section{System Dynamics Modelling of Deforestation Rate and Forest Rehabilitation in the Upstream of Ciliwung Watershed, Bogor Regency}

Andi Setyo Pambudi

\section{Introduction}

The problem of watershed, in general, is related to ecological balance which impacts on the carrying capacity of the environment and its components (Asdak, 2010; Chaidar et al., 2017). Area conversion in a watershed is a result of the human component in the form of population pressure on land as well as showing that there is a role for the community that affects the sustainability of natural resources (Watson et al., 2014; Chaidar, 2017). Land conversion is always associated with erosion (Arsyad, 2006). Pressured land is driven by factors that are unbalanced population growth rate with the availability of land so that increased activity and intensity of existing land and opening new land is difficult to avoid (Soemarwoto, 1999). Natural disasters such as landslides, floods, and droughts are impacts arising from conversion activities without regard to topographical, geological, and ecosystem carrying capacity (Sinukaban, 2007).

One of the strategic watersheds in Indonesia is the Ciliwung Watershed (Ruspendi et al., 2013). This happens considering that the downstream part of the watershed is the capital of the country of Indonesia so that the development and management of upstream is the concern of all parties (Ali et al., 2016). As a watershed ecosystem, changes in the upstream part of the watershed will affect the middle to downstream (Cumming, 2016; Chaidar et al., 2017). The Ciliwung watershed area is located in 2 provinces, namely Jawa Barat Province and DKI Jakarta Province or crosses Bogor Regency, Bogor City, Depok City, and Jakarta City, also empties into the Jakarta bay.

The rapid growth of development in the Ciliwung Watershed has resulted in reduced forested land and water catchment areas, both upstream, middle, and downstream watershed (Arifasihati \& Kaswanto, 2016). The Critical point is when the upstream area as a watershed buffer also experiences uncontrolled land conversion for various economic needs (Kholil \& Dewi, 2015). The government has been paying attention to this watershed since the 1960s, especially the Bopunjur area (Bogor, Puncak, and Cianjur). Most of the areas in the upper watershed of the Ciliwung are protected and cultivated functions for water catchment for the downstream areas (Suwarno et al., 2011 ; Ruspendi et al., 2013; Ali et al., 2016).

The health of a watershed is determined by the good condition of forest cover in the upstream area as a buffer for water systems (Bellfield et al., 2016; Kagoya et al., 2017; Tajbakhsh et al., 2018). Indonesia Law No. 41 of 1999 concerning Forestry article 18 contains a mandate for the Government to determine and maintain the adequacy of forest cover in each watershed area to optimize the environmental benefits, social benefits and economic benefits of the local community. Bappenas (2015) has mentioned that the Ciliwung Watershed is one of the watersheds that is very priority to be handled.

Forest rehabilitation policies implemented in Indonesia so far are inadequate to realize forest sustainability, either because that policies are inaccurate or cannot predict 
when they will be completed. Forest rehabilitation that occurs seems to only be an annual agenda without seeing the relationship between deforestation rate and rehabilitation rate carried out by the government as a scientific analysis. The watershed-scale development policy should ideally consider the components within it so that it requires further study.

This study seeks to understand the condition of rehabilitation and deforestation of forested land in Bogor Regency as the upstream of the Ciliwung Watershed which affects the water system of the downstream Ciliwung Watershed namely DKI Jakarta Province. Based on dynamics system modeling, it's expected that an ideal rehabilitation scenario that the government must undertake will be known to pursue deforestation rates in forested upstream watersheds (Contstanza \& Ruth, 1998; Soesilo \& Karuniasa, 2014).

\section{Materials and Method}

\subsection{Time and Location}

The research was carried out for 4 months start from concept, data collection, data analysis and report writing. The location is limited to the upstream Ciliwung Watershed in Bogor Regency as an integral part of the Ciliwung Watershed. Administratively the Ciliwung Watershed has a total area of 34,700 ha. The upstream part of the watershed has an area of 14,860 ha with total forest area located in Bogor Regency. Carrying capacity of the forest area or land area available in the upstream Ciliwung Watershed is 8,140 ha. 


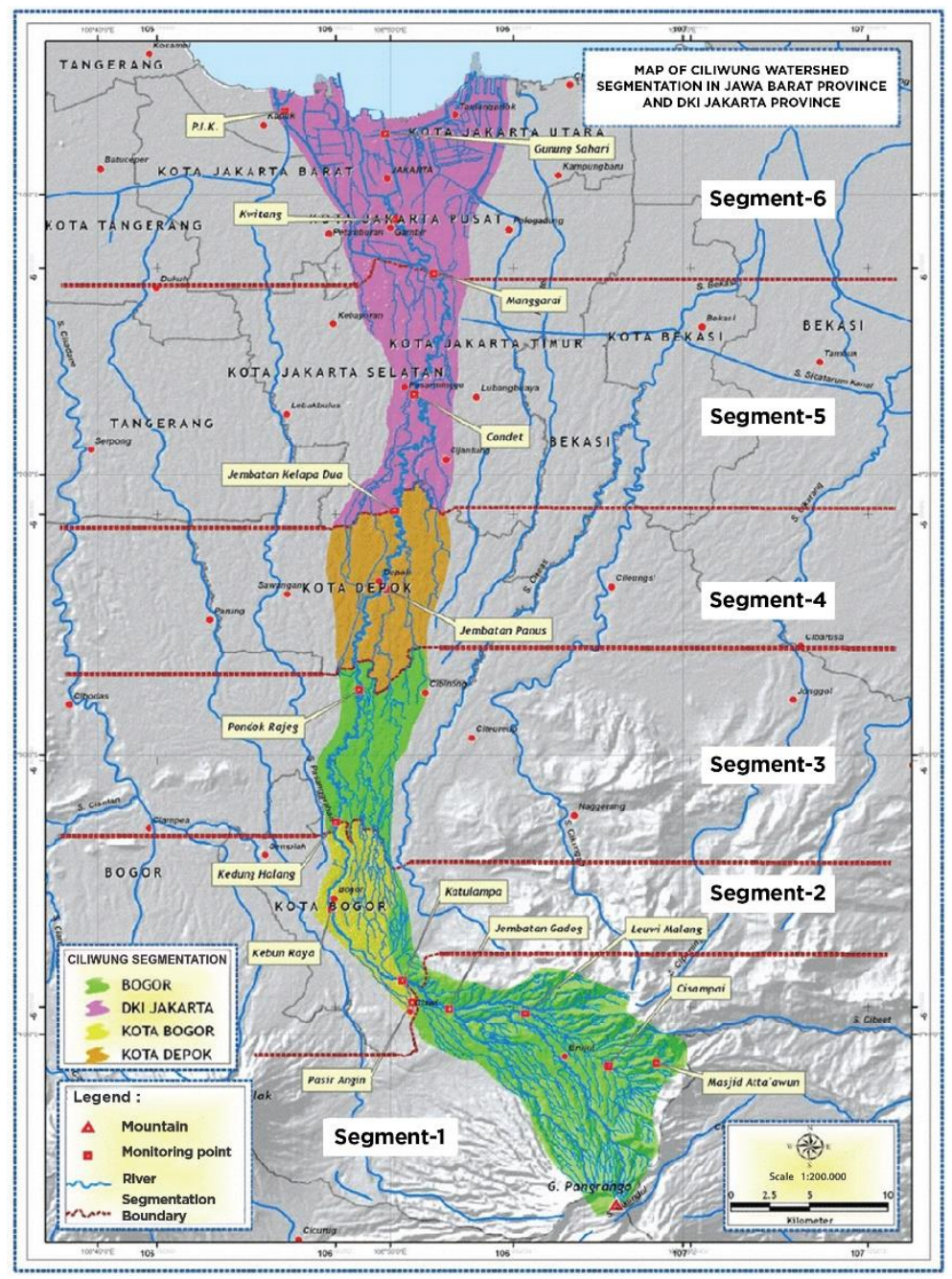

Figure 1. Research Sites

\subsection{Materials and Tools}

This study uses several secondary data from relevant agencies, especially from the Ministry of Environment and Forestry, the Provincial Government of DKI Jakarta and the Government of Bogor Regency. The selection of observation year period for modeling was 1992-2002, with the consideration that in that period there was a transition period from the "Orde Baru" to the "Orde Reformasi". This is intended to provide modeling information that more accurately represents the real conditions of land use change during the transition period. 
Andi Setyo Pambudi

Table 1. Changes in forested land area

\begin{tabular}{|c|c|}
\hline Year & Area of Forest Reference (ha) \\
\hline 1992 & 6,184 \\
\hline 1993 & 6,022 \\
\hline 1994 & 5,915 \\
\hline 1995 & 5,834 \\
\hline 1996 & 5,731 \\
\hline 1997 & 5.698 \\
\hline 1998 & 4,332 \\
\hline 1999 & 4,313 \\
\hline 2000 & 4,309 \\
\hline 2001 & 4,202 \\
\hline 2002 & 4,187 \\
\hline
\end{tabular}

The trend in forested land area in Bogor Regency continues to experience a reduction from year to year. The Ministry of Environment and Forestry noted that in 1992, forested land in the upstream Ciliwung watershed was 6,184 ha, and in 2002 it was 4,187 ha. The forest area available in Bogor Regency is located at an altitude area and is the main buffer for DKI Jakarta's water system so that the existence of forest cover needs to be maintained or increased in the area.

Deforestation rates in the forest area in the upstream Ciliwung watershed are triggered by the conversion of forested land to other uses because of the economic attraction of the tourism and plantation potential that triggers immigration or the entry of people into forest areas in the Cisarua, Megamendung, and Ciawi District. Immigration into forest areas is driven by economic attraction for tourism and plantation areas. Data from the Bogor Regency Government shows that on average every 36 people who enter (immigration) into these 3 districts lead to the conversion of 1 ha of forested land as a result of the existing economic attraction. Land conversion for plantation was recorded at 124 ha/year and for tourism covering $96 \mathrm{ha} /$ year. Immigration of the population to the 3 sub-districts encouraged another conversion, namely the conversion of functions from forested land to residential land.

\subsection{Research Methods}

The approach used is a mixed-method with system-dynamics based analysis method. Simulation setting modeling is done with Start Time $=1992$ and Stop Time $=2060$ and Time Step $=1$. The assumption used related to the conversion of function into residential land is that every 1 resident converts $100 \mathrm{~m}^{2}$ or $0.01 \mathrm{ha} /$ person. With the available budget and based on certain considerations, the government annually allocates a state budget to carry out rehabilitation with the ability to rehabilitate $3 \% /$ year of existing forested land.

Relationships between variables in Stock Flow Diagrams (SFD) framework involve equations that are entered, especially components such as auxiliary, inflow, or out-flow. The 
equation can be in the form of simple mathematical, such as addition, subtraction, division, and/or multiplication. The software used is Powersim Studio 10 and Microsoft Excel 2019.

\section{RESULTS AND DISCUSSION}

The environment is defined as the area (region, etc.) as the boundary of economic activity, which influences the development of life in it (Common \& Stagl 2005; Bellfield et al., 2016). Dwellings or hydrological containers of economic activity based on the environment are described as a watershed (Common \& Stagl, 2005; Miller \& Spoolman, 2015). Within the watershed scope that affects modeling, there are at least 5 related variable.

Based on the existing story and modeling problems, the variables and their definitions are as described in Table 2 .

Table 2. Definition of Operational Variable

\begin{tabular}{|c|c|c|}
\hline No. & Variable & Operational Definition \\
\hline 1. & Forested Land & $\begin{array}{l}\text { Land that has forest cover that affects the water system of ha } \\
\text { watershed }\end{array}$ \\
\hline 2. & Deforestation & $\begin{array}{l}\text { The rate of forested land area reduced due to human ha/year } \\
\text { activities as a result of the economic attractiveness and } \\
\text { land requirements for new settlements }\end{array}$ \\
\hline 3. & Rehabilitation & $\begin{array}{l}\text { The rate of forested land area returned/conserved ha/year } \\
\text { according to its original function }\end{array}$ \\
\hline 4. & Immigration & $\begin{array}{l}\text { People entering forested land due to economic people } \\
\text { attractiveness }\end{array}$ \\
\hline 5. & $\begin{array}{l}\text { The Economic } \\
\text { Attractiveness }\end{array}$ & $\begin{array}{l}\text { Factors that determine the deforestation rate and - } \\
\text { immigration in forested land areas }\end{array}$ \\
\hline
\end{tabular}

Forested land experiences a broad downward trend from year to year caused by deforestation triggered by 2 things namely economic attractiveness and conversion to new residential land as a result of immigration.

By following the concept of the balance sheet in environmental economics (Common $\&$ Stagl, 2005; Suparmoko, 2016), some variables are additive and some other are reducing. In the context of the developed CLD, variables that add to in-flow are described as rehabilitation (determined by government policy), while variables that reduce to out-flow are then described as deforestation. Deforestation is affected by immigration and the need for residential land due to economic attractiveness. 


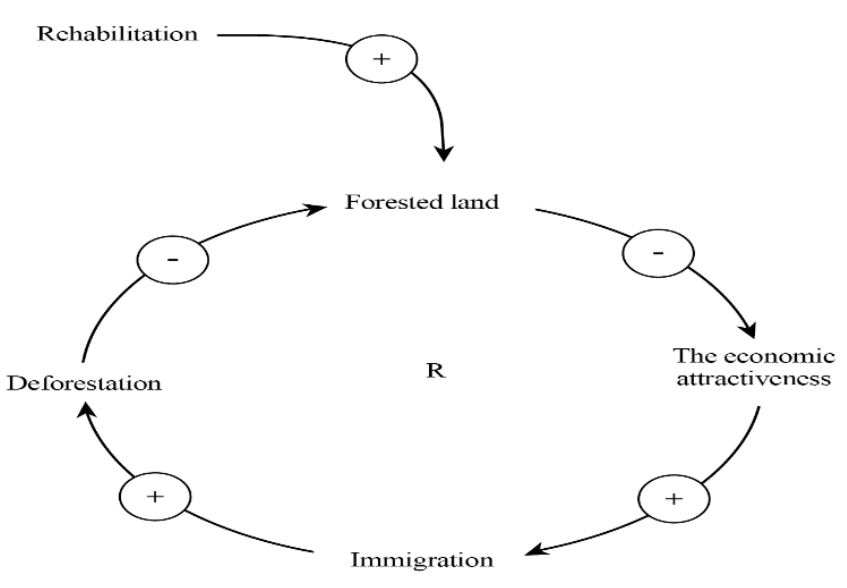

Figure 2. Causal Loop Diagram (CLD) of the Ciliwung Watershed Conversation Model Source: Analysis Results, 2020

Based on the causal intersection diagram, some explanations related to the diagram are as follows:

a) The linkage or relationship between forested land and economic attractiveness is negative (-). The less forested land, the more economic attractiveness will be. Economic attractiveness arises after forested land has become another form of land so that it can be used for economic activities such as tourism and plantations.

b) The linkage or relationship between economic attractiveness and immigration is positive $(+)$. The higher economic attractiveness, the more people enter (immigrate) into forested land.

c) The linkage or relationship between immigration and deforestation is positive $(+)$. The higher the number of people entering forested land due to economic attractiveness and housing needs, the greater the deforestation.

d) The linkage or relationship between deforestation and forested land is negative (-). The higher or greater the deforestation, the less forested/ narrower the area of forest.

e) The linkage or relationship between rehabilitation and forested land is positive (+). The more forested land rehabilitated by the government, the more forested land will increase.

Based on the CLD that was compiled in the previous section, a Stock Flow Diagram (SFD) was constructed involving several assistance variables (Sterman, 2004). These support variables are needed so that the calculation of the model makes more sense and reflects reality. Overall, the SFD constructed has 5 main variables as stated in the CLD, namely forested land area, rehabilitation, deforestation, immigration and economic attractiveness.

Assistance variables are derived to accommodate the lack of these main variables. This structure includes several important components adopting the essence of System Dynamics theory, namely stock, flow, and feedback (Sterman, 2004). To be easily understood, an 
explanation of SFD is elaborated on the basis of color. The red color represents a factor that causes a reduction in the area of forested land, the green color represents a factor that increases the area of forested land and the blue color represents the stock. The full SFD structure is illustrated in Figure 3.

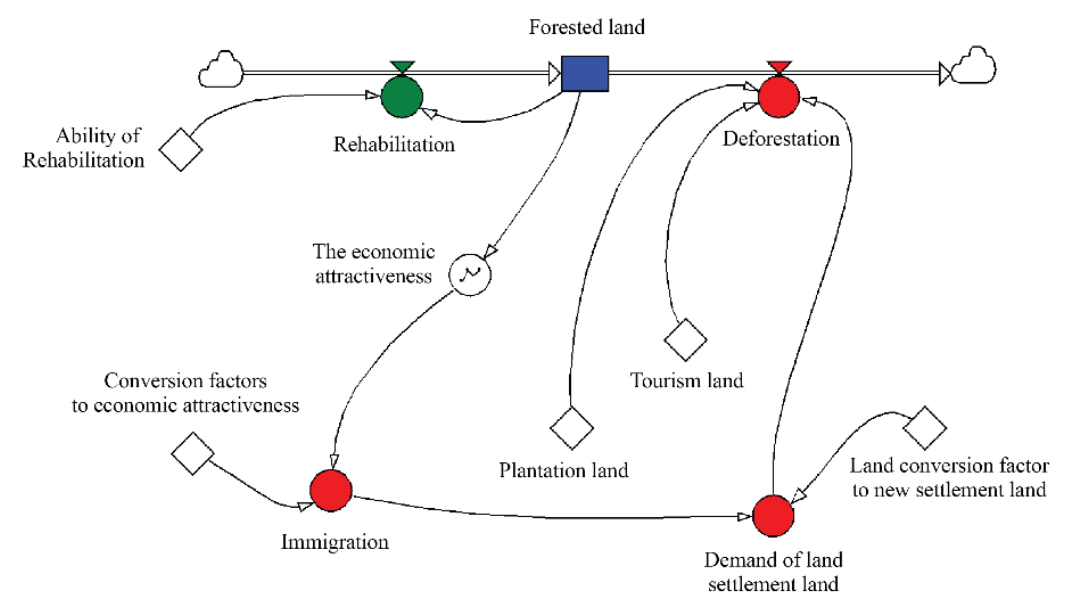

Figure 3. Stock Flow Diagram (SFD) of the Ciliwung Watershed Conservation Model

$$
\text { Source: Analysis Results }
$$

Forested land becomes a stock whose value continues to change over time. Forested land has in-flow in the form of rehabilitation rate in ha / year and out-flow in the form of deforestation also in ha / year. The rehabilitation rate is influenced by the ability scores the government budget spent on rehabilitation that is converted in units of \% / year. As an initial reference, the forested land area included in the SFD value is the area of forested land in the Ciliwung watershed in 1992 which was 6,184 with units of ha or hectares.

Relationships between variables in the SFD framework involve equations that are entered, especially components such as auxiliary, inflow, or out-flow. The equation in question can be in the form of simple mathematical equations, such as addition, subtraction, division, and/or multiplication, to the use of functions provided by Powersim Studio 10.

When compared to the reference data of forested land stock with the results of the simulation, found graphically similar shapes, both of which have decreased from year to year. The condition of reference forested land experienced a sharp drop or decline seen in 19971998. Based on the information obtained by the author from BPDAS Citarum Ciliwung, during the year political reformation events occurred in Indonesia so that people tend to illegally encroach on forest areas with state control that is not optimal (the transition period). 


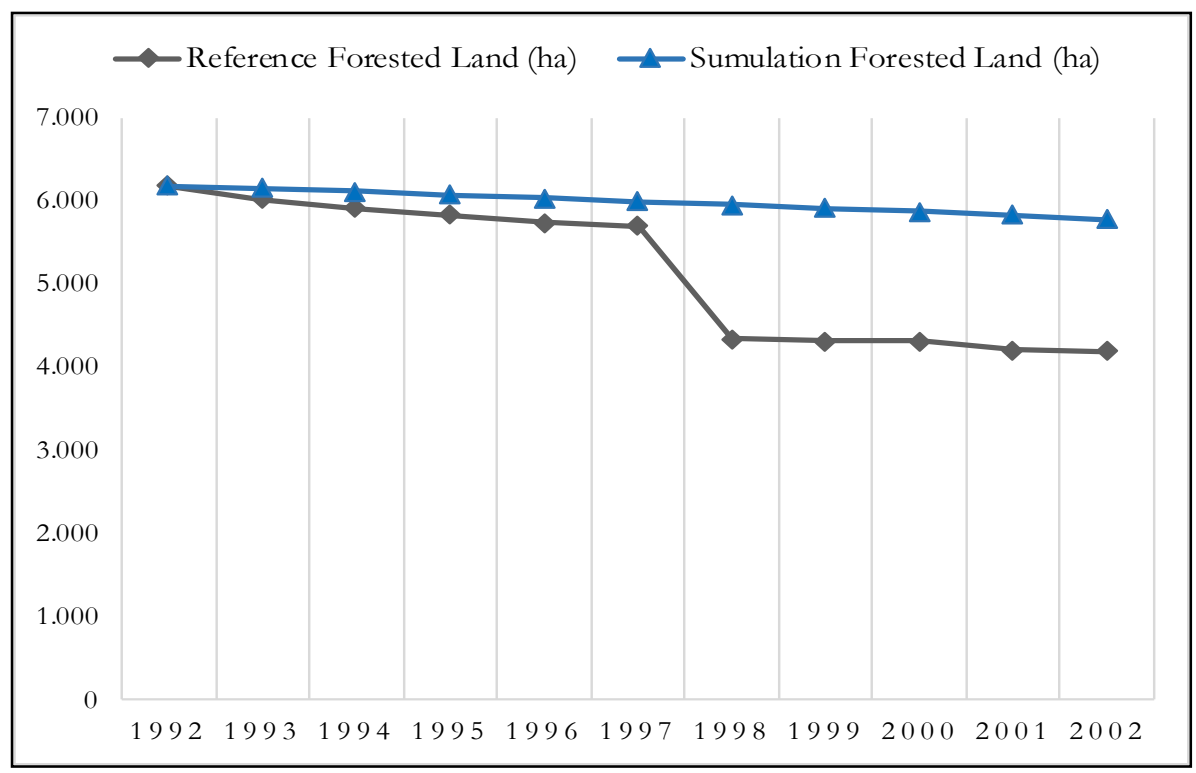

Figure 4. Comparison of Forested Land Reference and Simulation

Source: Analysis Results

\section{Model Assumptions}

The assumptions used in the Ciliwung watershed conservation model are as follows:

a) Emigration flow (outgoing migration) is so small that it is assumed to be zero.

b) The population factor considered in the model is only the influx of people (immigration) due to economic attractiveness so as to increase the population in the forested area, not taking into account the birth and death factors at the location.

c) The rehabilitation policy is assumed to be successful as a plant in accordance with previous forest functions, without considering crop failure, climate, natural disasters and price changes.

\section{Model Validation}

Model validation is carried out on 2 types of activities, namely:

a) Visual Validation: see the pattern of Reinforcing $(\mathrm{R})$ behavior of the positive feedback process on the CLD, so the possibility is that the graph will take the form of exponential growth or collapse. 


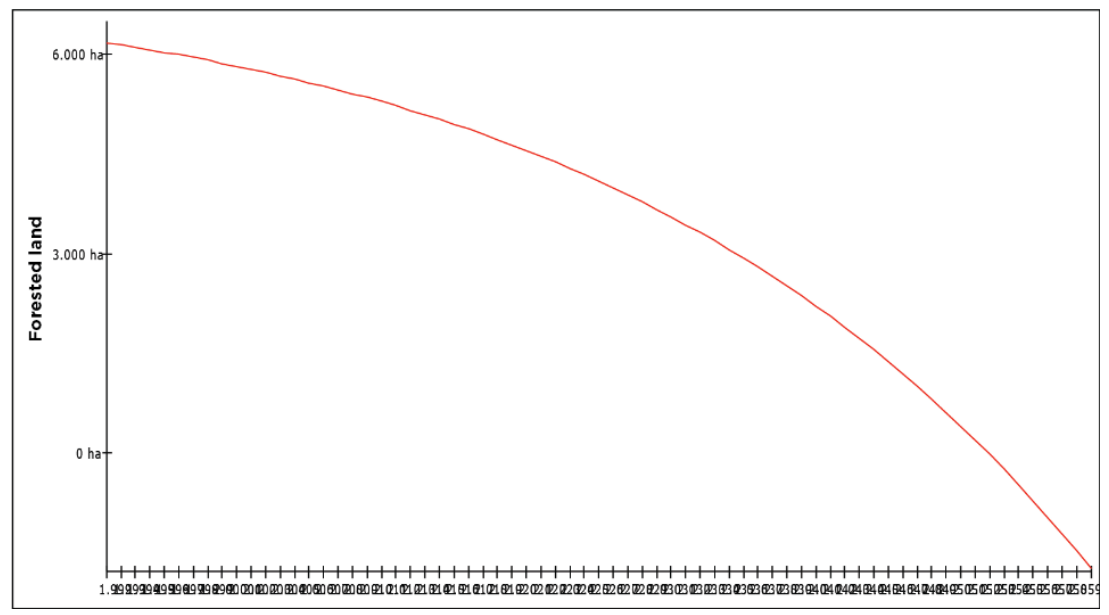

Figure 4. Pattern of Area of Forested Land in Real Conditions in the Upstream Ciliwung Watershed Source: Analysis Results

If see the forested land graph model after running it is known that the graph pattern is collapse so that the model is visually declared valid.

b) Statistical Validation: using the Average Mean Error (AME) formula, which is a statistical validation test with an average deviation test.

Formula:

$$
\begin{aligned}
& A M E=\frac{S-R}{R} \\
& \text { Explanation: } \\
& \mathrm{S}=\text { Values of Simulation Results Variables } \\
& \mathrm{R}=\text { Riil Real Power Variable Value }
\end{aligned}
$$

The model is declared valid if the results of the statistical calculation of the AME value $\leq 0.30$ due to variable conditions are not controlled (there are climate factors, disasters and others). 
Table 3. Results of AME Calculation of the Ciliwung Watershed Conservation Model

\begin{tabular}{ccc}
\hline Year & Forested land reference (ha) & Forested land simulation (ha) \\
\hline 1992 & 6.184 & 6.184 \\
\hline 1993 & 6.022 & 6.149 \\
\hline 1994 & 5.915 & 6.113 \\
\hline 1995 & 5.834 & 6.076 \\
\hline 1996 & 5.731 & 6.038 \\
\hline 1997 & 5.698 & 5.998 \\
\hline 1998 & 4.332 & 5.957 \\
\hline 1999 & 4.313 & 5.915 \\
\hline 2000 & 4.309 & 5.872 \\
\hline 2001 & 4.202 & 5.827 \\
\hline 2002 & 4.187 & 5.780 \\
\hline Average & 5.157 & 5.992 \\
\hline & Source: Analysis Results & 0,1618 \\
\hline
\end{tabular}

Based on the calculation above, it was concluded that with an AME value of $16.18 \%$ or 0.1618 (meaning AME value $\leq 0.30$ ), then the model statistically declared valid.

\section{Reference Simulation Results}

Based on forested land reference data obtained from BPDAS Citarum - Ciliwung in 2003, it can be seen in the reference simulation graph in Figure 5. Based on information obtained by the author, in that year, there was political reforms in Indonesia that make people tend to illegally encroach forest areas with unoptimal control state (transition period).

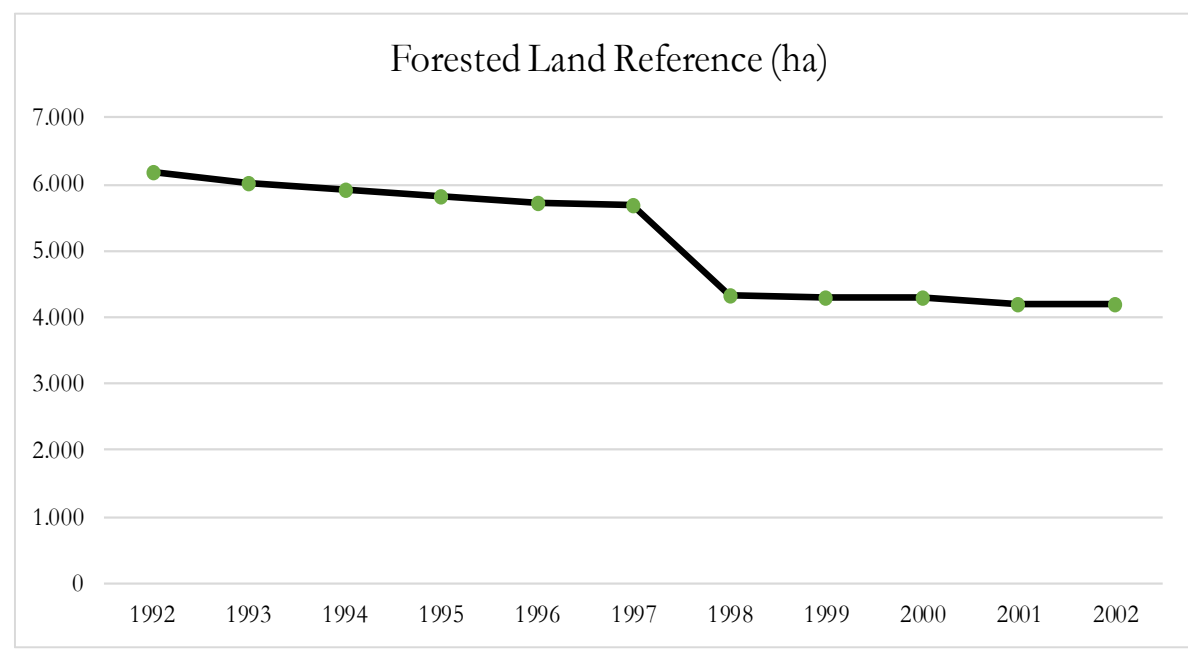

Figure 5. Forest Simulation Results Based on Reference Data 


\section{Simulation Result of Business As Usual Model}

Based on the simulation, it was found that the rate of rehabilitation cannot keep up with the rate of deforestation so that the forest area decreased from year to year. In business as usual (BAU) condition, the area of forested land decreases with increasing deforestation. The increase in the rate of deforestation is influenced by increasing rates of immigration or people entering forested areas due to economic attractiveness.

\section{Scenario 1: Business As Usual}
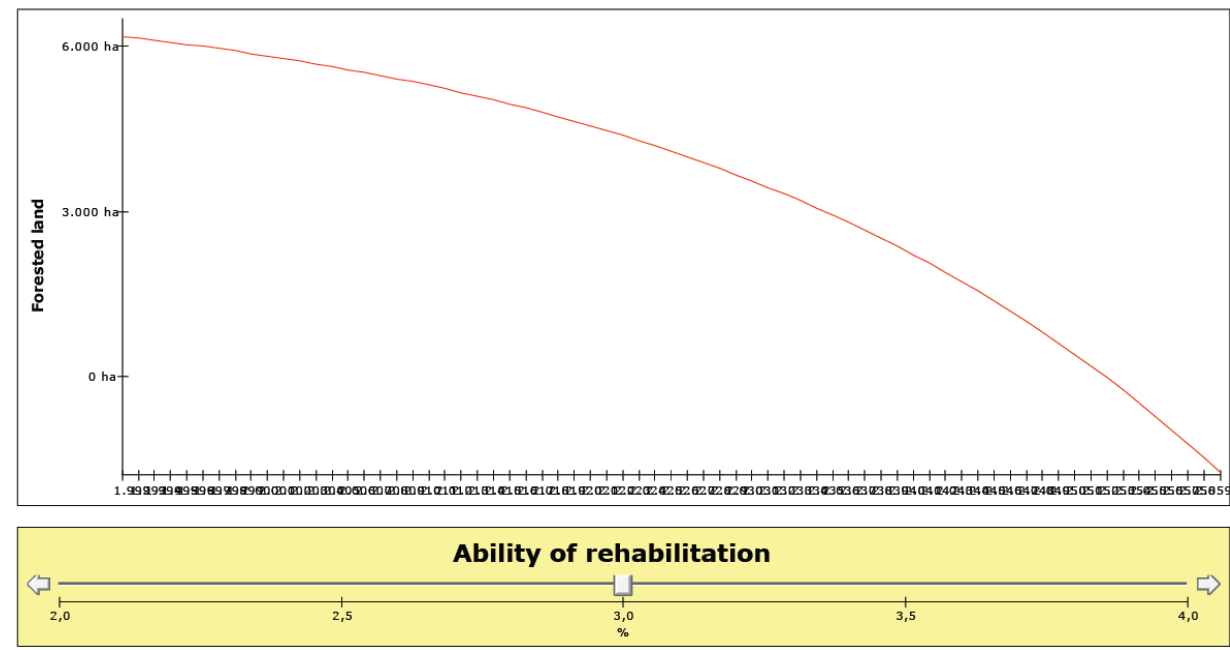

Figure 6. Business As Usual Forested Land (BAU) Phenomenon Trend

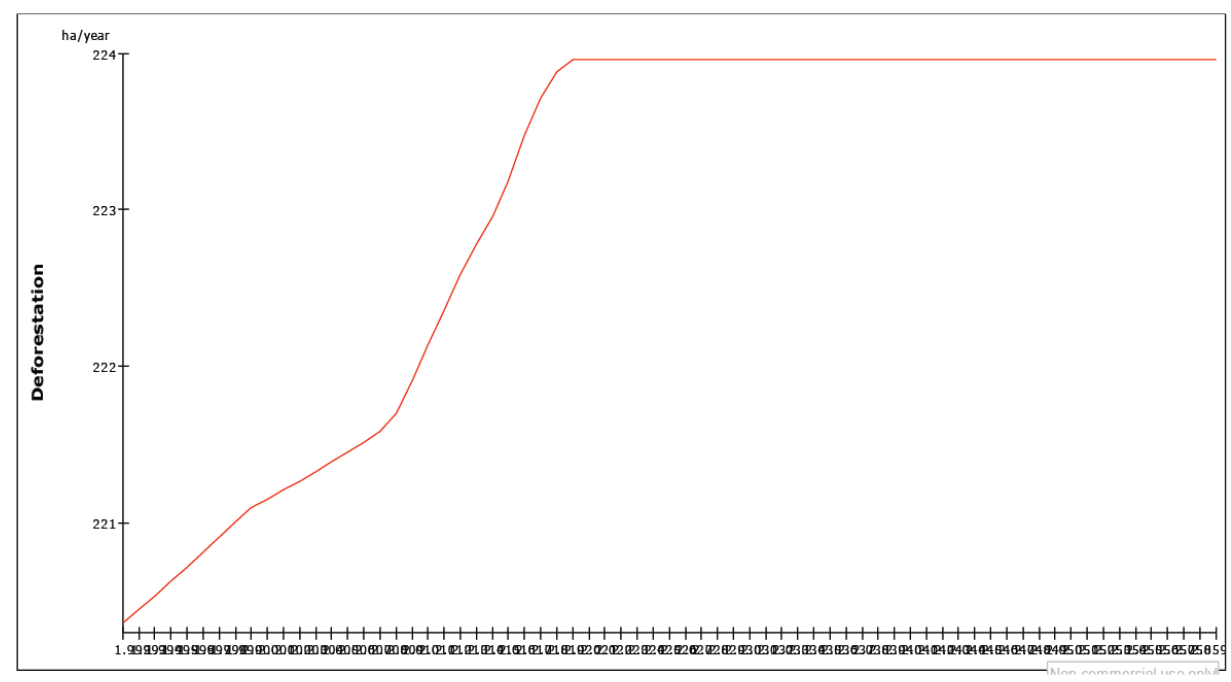

Figure 7. Business As Usual (BAU) Deforestation Rate Trends Phenomenon 


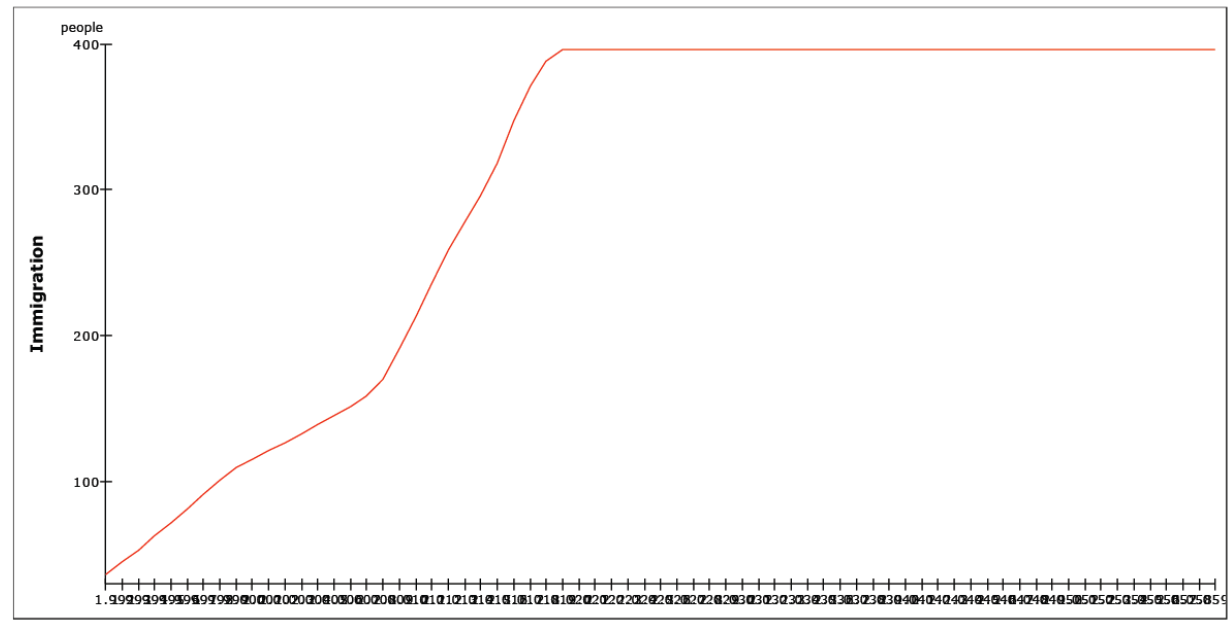

Figure 8. Business As Usual (BAU) Immigration Phenomenon Trends

Figures 7 and 8 illustrate that there is a clear link in the form of the same graphic pattern between trends in deforestation rates and immigration trends in forested land in the upper Ciliwung watershed. The more people who enter (immigration) into forested land, the higher the rate of deforestation. This has also triggered a decline in forested land area due to land conversion, both due to economic incentives and shifting of functions for new residential land. 
Andi Setyo Pambudi

Table 4. Results of Forestry Land Simulation, Deforestation and Upstream

\begin{tabular}{|c|c|c|c|c|}
\hline \multicolumn{5}{|c|}{ (ha) } \\
\hline year & Forested land & Deforestation & Rehabilitation & \\
\hline 1.992 & $6.184,00$ & 220,36 & 185,52 & - \\
\hline 1.993 & $6.149,16$ & 220,44 & 184,47 & \\
\hline 1.994 & $6.113,19$ & 220,53 & 183,40 & \\
\hline 1.995 & $6.076,05$ & 220,62 & 182,28 & \\
\hline 1.996 & $6.037,71$ & 220,71 & 181,13 & \\
\hline 1.997 & $5.998,13$ & 220,81 & 179,94 & \\
\hline 1.998 & $5.957,27$ & 220,91 & 178,72 & \\
\hline 1.999 & $5.915,08$ & 221,01 & 177,45 & \\
\hline 2.000 & $5.871,52$ & 221,10 & 176,15 & \\
\hline 2.001 & $5.826,57$ & 221,15 & 174,80 & \\
\hline 2.002 & $5.780,21$ & 221,21 & 173,41 & \\
\hline 2.003 & $5.732,41$ & 221,27 & 171,97 & \\
\hline 2.004 & $5.683,12$ & 221,32 & 170,49 & \\
\hline 2.005 & $5.632,28$ & 221,39 & 168,97 & \\
\hline 2.006 & $5.579,87$ & 221,45 & 167,40 & \\
\hline 2.007 & $5.525,81$ & 221,51 & 165,77 & \\
\hline 2.008 & $5.470,08$ & 221,58 & 164,10 & \\
\hline 2.009 & $5.412,60$ & 221,70 & 162,38 & \\
\hline 2.010 & $5.353,27$ & 221,91 & 160,60 & \\
\hline 2.011 & $5.291,96$ & 222,13 & 158,76 & \\
\hline 2.012 & $5.228,58$ & 222,36 & 156,86 & \\
\hline 2.013 & $5.163,08$ & 222,58 & 154,89 & \\
\hline 2.014 & $5.095,39$ & 222,78 & 152,86 & \\
\hline 2.015 & $5.025,47$ & 222,96 & 150,76 & \\
\hline 2.016 & $4.953,28$ & 223,18 & 148,60 & \\
\hline 2.017 & $4.878,69$ & 223,47 & 146,36 & \\
\hline 2.018 & $4.801,58$ & 223,71 & 144,05 & \\
\hline 2.019 & $4.721,91$ & 223,88 & 141,66 & \\
\hline 2.020 & $4.639,69$ & 223,96 & 139,19 & \\
\hline 2.021 & $4.554,92$ & 223,96 & 136,65 & \\
\hline 2.022 & $4.467,61$ & 223,96 & 134,03 & \\
\hline 2.023 & $4.377,67$ & 223,96 & 131,33 & \\
\hline 2.024 & $4.285,04$ & 223,96 & 128,55 & \\
\hline 2.025 & $4.189,64$ & 223,96 & 125,69 & \\
\hline 2.026 & $4.091,36$ & 223,96 & 122,74 & \\
\hline 2.027 & $3.990,15$ & 223,96 & 119,70 & \\
\hline 2.028 & $3.885,89$ & 223,96 & 116,58 & \\
\hline 2.029 & $3.778,51$ & 223,96 & 113,36 & \\
\hline 2.030 & $3.667,90$ & 223,96 & 110,04 & \\
\hline 2.031 & $3.553,98$ & 223,96 & 106,62 & \\
\hline 2.032 & $3.436,64$ & 223,96 & 103,10 & \\
\hline 2.033 & $3.315,78$ & 223,96 & 99,47 & \\
\hline 2.034 & $3.191,29$ & 223,96 & 95,74 & \\
\hline 2.035 & $3.063,07$ & 223,96 & 91,89 & \\
\hline 2.036 & $2.931,00$ & 223,96 & 87,93 & \\
\hline 2.037 & $2.794,97$ & 223,96 & 83,85 & \\
\hline 2.038 & $2.654,86$ & 223,96 & 79,65 & \\
\hline 2.039 & $2.510,55$ & 223,96 & 75,32 & \\
\hline 2.040 & $2.361,90$ & 223,96 & 70,86 & \\
\hline 2.041 & $2.208,80$ & 223,96 & 66,26 & \\
\hline 2.042 & $2.051,10$ & 223,96 & 61,53 & \\
\hline 2.043 & $1.888,68$ & 223,96 & 56,66 & \\
\hline 2.044 & $1.721,38$ & 223,96 & 51,64 & \\
\hline 2.045 & $1.549,06$ & 223,96 & 46,47 & \\
\hline 2.046 & $1.371,57$ & 223,96 & 41,15 & \\
\hline 2.047 & $1.188,76$ & 223,96 & 35,66 & \\
\hline 2.048 & $1.000,46$ & 223,96 & 30,01 & \\
\hline 2.049 & 806,51 & 223,96 & 24,20 & \\
\hline 2.050 & 606,75 & 223,96 & 18,20 & \\
\hline 2.051 & 400,99 & 223,96 & 12,03 & \\
\hline 2.052 & 189,06 & 223,96 & 5,67 & \\
\hline 2.053 & $-29,23$ & 223,96 & $-0,88$ & \\
\hline 2.054 & $-254,06$ & 223,96 & $-7,62$ & \\
\hline 2.055 & $-485,64$ & 223,96 & $-14,57$ & \\
\hline 2.056 & $-724,17$ & 223,96 & $-21,73$ & \\
\hline 2.057 & $-969,86$ & 223,96 & $-29,10$ & \\
\hline 2.058 & $-1.222,92$ & 223,96 & $-36,69$ & \\
\hline 2.059 & $-1.483,56$ & 223,96 & $-44,51$ & \\
\hline 2.060 & $-1.752,03$ & 223,96 & $-52,56$ & $=$ \\
\hline
\end{tabular}




\section{Rehabilitation of BAU Conditions in 1992-2060}

The interesting thing from the table is that in business as usual, or with the rehabilitation ability owned by the government which $3 \%$ / year, so the forested land area will be used up between the years 2052-2053.

The modeling approach is a learning process in understanding decision making amid dynamic reality situations (Costanza \& Ruth, 1998). This learning process is obtained by giving intervention in the model structure. In the context of modeling, interventions on variables in the SFD aim to increase the pace of rehabilitation through interventions of increasing government budget. Some simulations are carried out to get stock charts so they don't collapse as business as usual conditions. An intervention in increasing the value of the constant "rehabilitation capability" is needed on the forested land stock.

\section{Future Scenario Model Simulation Results}

Based on available data, the government's rehabilitation capability is $3 \%$ / year. In order to catch up with the rate of deforestation, the government needs to increase its budget allocation so that rehabilitation capability also increases. In the context of existing budget efficiency, the most optimal land capability scenarios are needed to overcome future problems that also consider the area of land available for forest areas.

Scenario 2: Rehabilitation capability has been increased from $3 \%$ / year to $3.1 \%$ / year to $3.8 \%$ / year
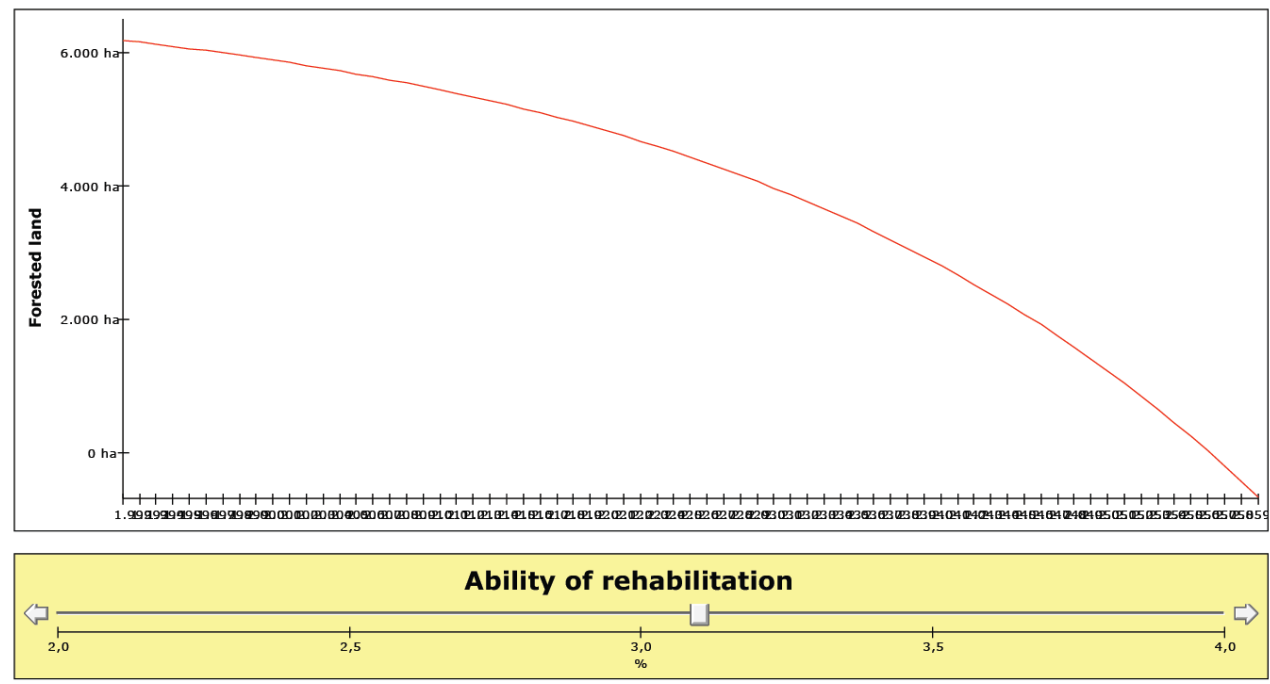

Figure 9. Scenario Result of Rehabilitation Capability Scenario of 3.1\% / year

The graph above shows that with the scenario of increasing rehabilitation capability by $0.1 \%$ of business as usual, the area of forested land will continue to fall (collapse). It can be concluded temporarily that the scenario for increasing rehabilitation capability from $3 \%$ to $3.1 \%$ does not significantly affect the pattern of forested land area in the future time period. The scenario can be continued to $3.2 \%$ / year, 3.3\% / year, $3.4 \%$ / year, $3.5 \%$ / year, $3.6 \%$ / year. $3.7 \%$ / year, up to $3.8 \% /$ year. 
Andi Setyo Pambudi

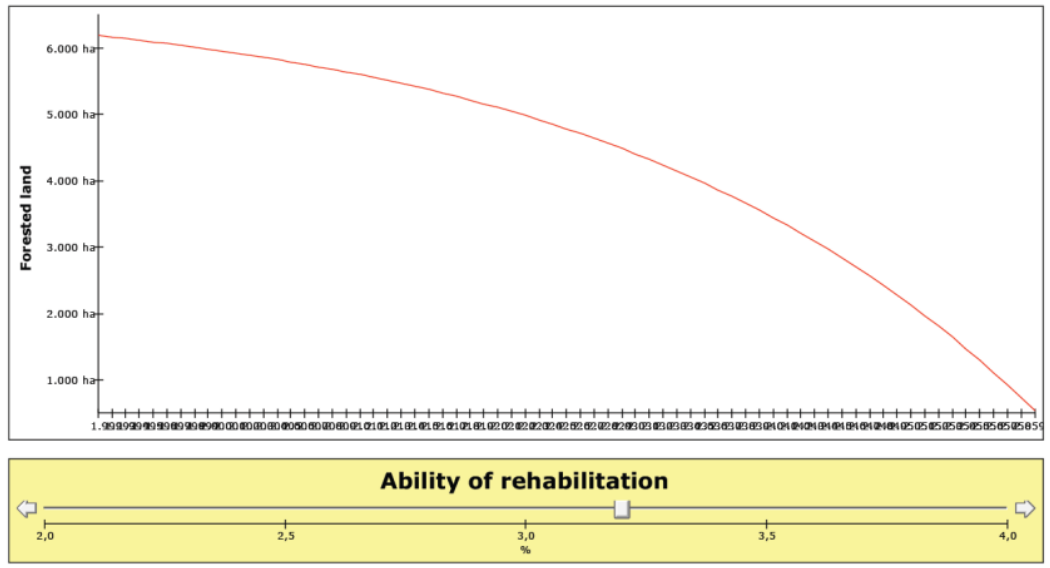

Figure 10. Scenario Result of the Rehabilitation Capacity 3.2\% / year

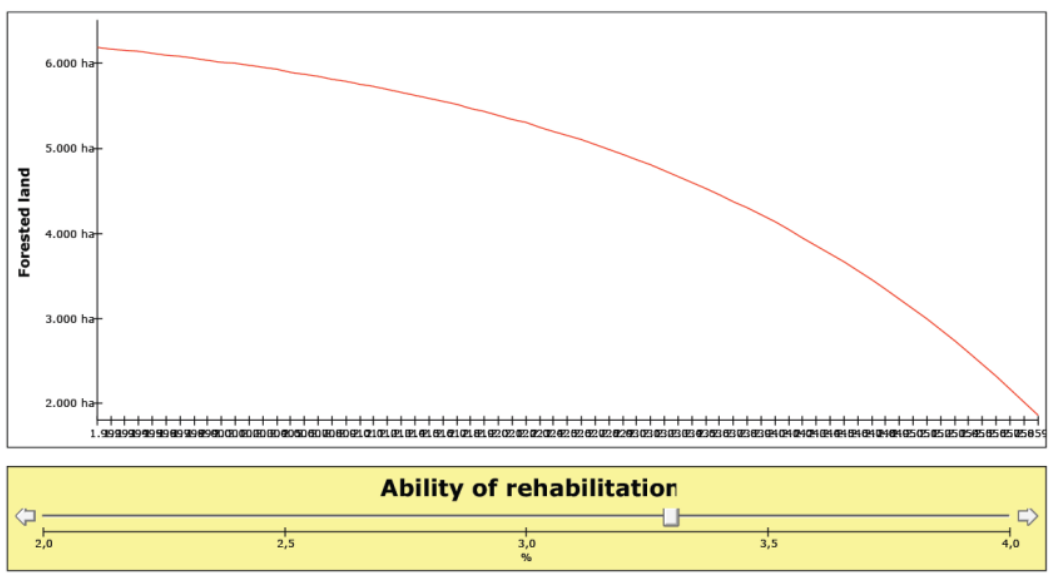

Figure 11. Scenario Result of the Rehabilitation Capacity 3.3\% / year

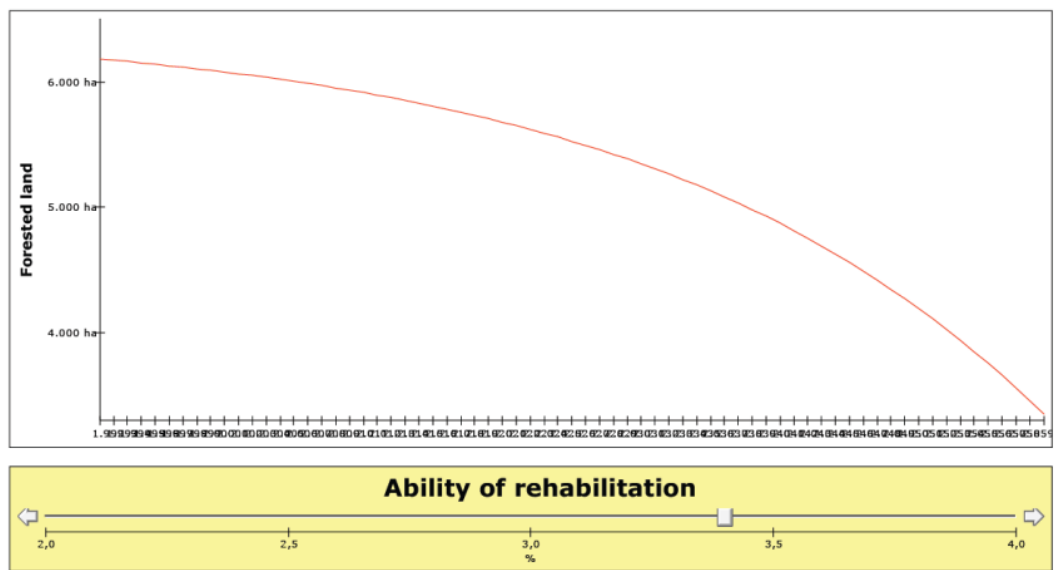

Figure 12. Scenario Result of the Rehabilitation Capacity 3.4\% / year 
Andi Setyo Pambudi

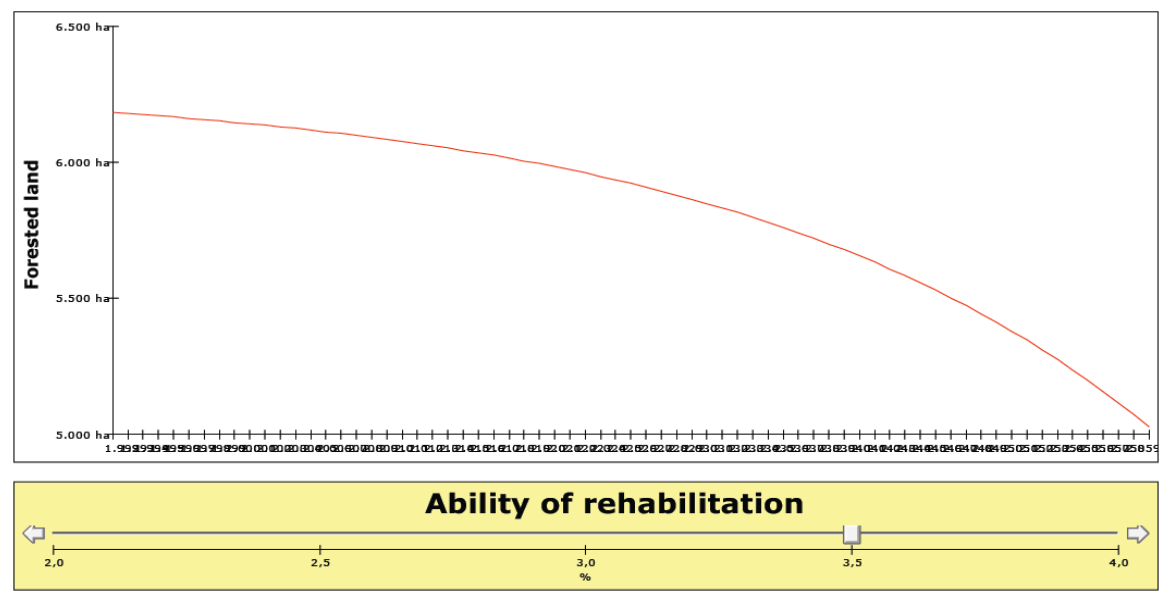

Figure 13. Scenario Result of the Rehabilitation Capability of $3.5 \%$ / year

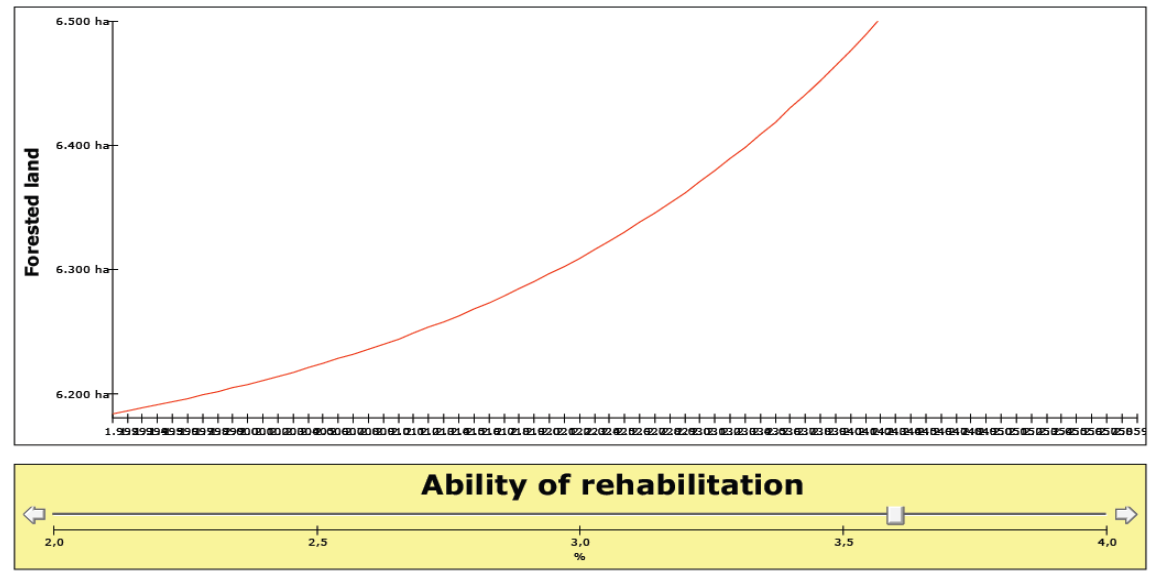

Figure 14. Scenario Result of the Rehabilitation Capability of $3.6 \%$ / year

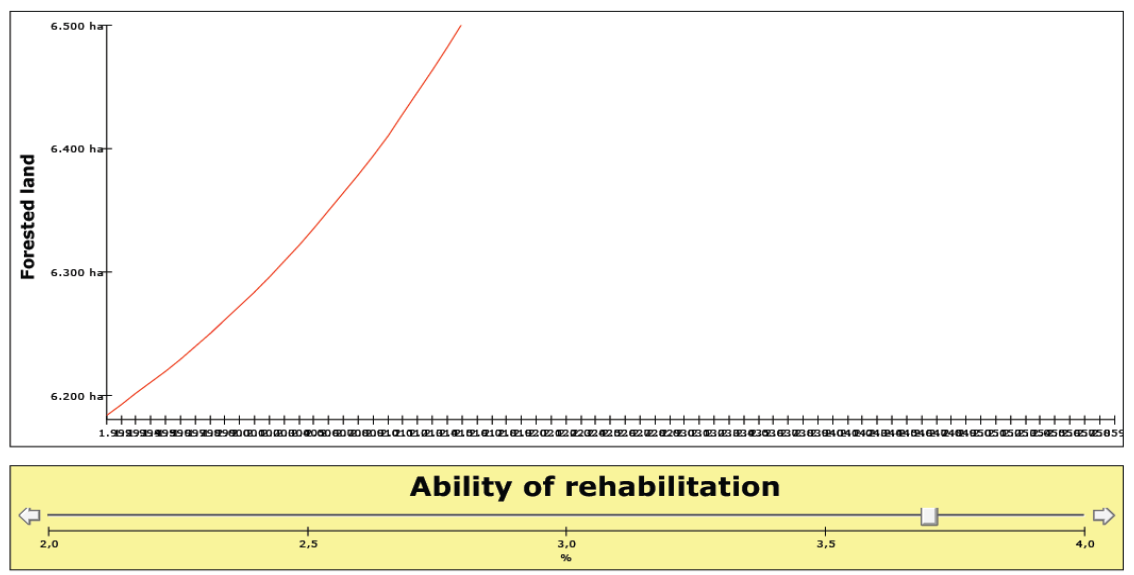

Figure 15. Scenario Result of the Rehabilitation Capacity 3.7\% / year 


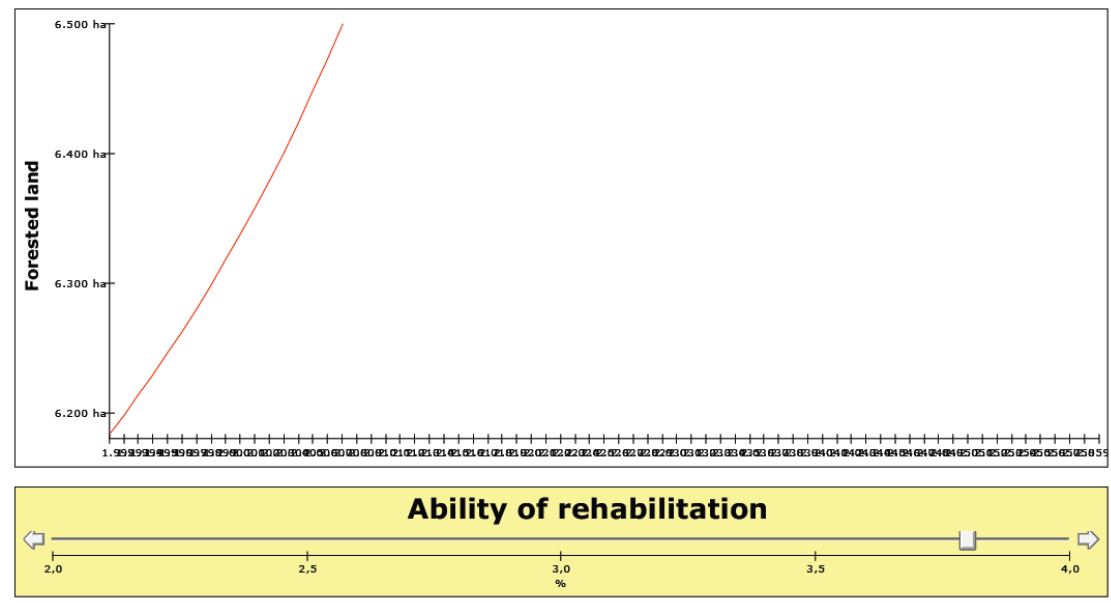

Figure 16. Scenario Result of Rehabilitation Capability 3.8\% / year

\section{Conclusion}

From the 8 alternative scenarios above, it is known that the rehabilitation capability scenario is increased to $\mathbf{3 . 6 \%}$ / year which is the most optimal (minimum value) to catch the rate of deforestation in the upstream of Ciliwung watershed. This scenario in 2060 produces a forested land area of $6.817,80$ ha. The area of forested land in 2060 is still below the available land area for forest areas (carrying capacity of forest areas) which is 8,140 ha (BPDAS Citarum Ciliwung, 2013). If the simulation setting is extended to 2100 , then the maximum area of forested land in 2090 will be $8,134.05$ ha (still below the carrying capacity of the available forest area). In 2091, the area of forested land was 8,206.51 ha, exceeding the carrying capacity of the available forest area.

\section{References}

Ali, M., Hadi, S., \& Sulistyantara, B. (2016). Study on Land Cover Change of Ciliwung Downstream Watershed with Spatial Dynamic Approach. Procedia - Social and Behavioral Sciences, 227, 52-59. doi:10.1016/j.sbspro.2016.06.042

Arifasihati, Y., \& Kaswanto. (2016). Analysis of Land Use and Cover Changes in Ciliwung and Cisadane Watershed in three Decades. Procedia Environmental Sciences, 33, 465-469. doi:10.1016/j.proenv.2016.03.098

Arsyad, Sitanala. (2006). Soil and Water Conservation. Bogor: IPB Press

Asdak, Chay. (2010). Hidrologi dan Pengelolaan Daerah Aliran Sungai. Edisi Kelima (Hydrology and Management of Watersheds. Fifth Edition). Yogyakarta: Gadjah Mada University Press.

Bappenas (2015). Kajian Pengaruh Kebijakan Konservasi Sumber Daya Air di dalam DAS Terhadap Sektor Kehutanan dan Sektor lainnya (Study on the Effect of Water 
Resources Conservation Policy in the Watershed on the Forestry Sector and Other Sectors). Jakarta: Bappenas.

Chaidar, A.N., Soekarno, I., Wiyono, A. \& Nugroho, J. (2017). Spatial Analysis of Erosion and Land Criticality of The Upstream Citarum Watershed. International Journal of GEOMATE, September, 2017, Volume 13. DOI: 10.21660/2017.37.34572

Common, M. \& Stagl, S. (2005). Ecological Economic: An Introduction. New York: Cambridge University Press.

Costanza, R., \& Ruth, M. (1998). Using Dynamic Modeling to Scope Environmental Problems and Build Consensus. Environmental Management, 22(2), 183195. doi:10.1007/s002679900095

Cumming, G. S. (2016). The relevance and resilience of protected areas in the Anthropocene. Anthropocene, 13, 46-56. doi:10.1016/j.ancene.2016.03.003

Bellfield, B., Leggett, M., Trivedi, M., Pareira, J., Gangga, A. (2016). How Can Indonesia Achieve Water, Energy and Food Security?. Jakarta: WCS and Global Canopy Programme.

GoI. (1999). Undang-undang No. 41 Tahun 1999 tentang Kehutanan (Laws No.41 of 1999 concerning Forestry). Jakarta: Republic of Indonesia

Kagoya, S., Paudel, K. P., \& Daniel, N. L. (2017). Awareness and Adoption of Soil and Water Conservation Technologies in a Developing Country: A Case of Nabajuzi Watershed in Central Uganda. Environmental Management, 61(2), 188196. doi:10.1007/s00267-017-0967-4

Kholil \& Dewi, I.K. (2015). Evaluation of Land Use Change in the Upstream of Ciliwung Watershed to Ensure Sustainability of Water Resources. Asian Journal of Water, Environment and Pollution, Vol. 12, No. 1 (2015), pp. 11-19.

Miller, G.T. \& S.E. Spoolman. (2015). Living in the Environment : Concepts, Connections and Solutions. Seventeenth edition. Brooks/Cole, Belmont, CA (USA)

Mtibaa, S., Hotta, N., \& Irie, M. (2018). Analysis of the efficacy and cost-effectiveness of best management practices for controlling sediment yield: A case study of the Joumine watershed, Tunisia. Science of The Total Environment, 616-617, 116. doi:10.1016/j.scitotenv.2017.10.290

Sinukaban, Naik. (2007). The Role of Soil and Water Conservation in Watershed Management. Jakarta: Prosiding Bunga Rampai Soil and Water Conservation.

Soemarwoto, Otto. (1999). Analisis Dampak Lingkungan (Environmental Impact Analysis). Yogyakarta: Gadjah Mada University Press.

Soesilo, T. E. B., \& Karuniasa, M. (2014). System Dynamics Modeling: For Various Fields of Government and Business Policy Sciences. Jakarta: University of Indonesia Faculty of Economics Publisher Institute.

Sterman, J. D. (2004). Business Dynamics: System Thinking and Modelling for A Complex World. International Edition. McGraw Hill. 
Suwarno, J., Kartodihardjo, H., Pramudya, B. \& S. Rachman (2011). Policy Development of Sustainable Watershed Management of Upper Ciliwung, Bogor Regency. Journal of Forest Policy Analysis, 8(2): 11 5-131. ISSN 0216-0897

Ruspendi, D., Hadi, S., \& Rusdiana, O. (2013). Study of Land Cover Change in the Ciliwung Hulu Watershed Using a Dynamic Spatial Approach. Indonesian Landscape Journal. DOI: https://doi.org/10.29244/jli.2013.5.2.1-5

Tajbakhsh, S.M., Memarian, H. Kheyrkhah, A. (2018). A GIS-based integrative approach for land use optimization in a semi-arid watershed. Global Journal of Environmental Science Management, 4(1): 31-46. DOI: 10.22034/gjesm.2018.04.01.004

Watson, J. E. M., Dudley, N., Segan, D. B., \& Hockings, M. (2014). The performance and potential of protected areas. Nature, 515(7525), 67-73. doi:10.1038/nature13947 